\title{
Calprotectin in viral systemic infections-COVID-19 versus hepatitis C virus
}

\author{
Letitia Toma $^{1,2}\left(\right.$ Mihai Dodot $^{1,2} \cdot$ Anca Zgura $^{1} \cdot$ Nicolae Bacalbasa $^{1} \cdot$ Andrei Silaghi $^{1,2} \cdot$ Razvan Simu $^{1,2}$. \\ Teodora Isac ${ }^{1,2} \cdot$ Adriana Mercan-Stanciu ${ }^{1,2}$
}

Received: 10 May 2021 / Accepted: 5 July 2021 / Published online: 12 July 2021

(c) The Author(s), under exclusive licence to Springer Nature Switzerland AG 2021

\begin{abstract}
This study aims to evaluate differences in serum and fecal calprotectin in patients with HCV chronic hepatitis and COVID-19 infection and compare them to a control group. This observational study was performed between April 2020 and October 2020 in a single Internal Medicine center. We determined serum and fecal calprotectin, as well as levels of transaminases, C-reactive protein, ferritin, in 25 patients with COVID-19 infection, 30 patients with active HCV chronic infection and 38 patients with cured HCV infection. Serum levels of ALT, AST, C-reactive protein and ferritin were significantly higher in patients with COVID-19 infection (mean values of $127 \mathrm{IU} / \mathrm{mL}, 135 \mathrm{IU} / \mathrm{mL}, 123 \mathrm{mg} / \mathrm{L}$ and $1034 \mathrm{ng} / \mathrm{mL}$, respectively) than in patients with active HCV infection (mean values of $68 \mathrm{IU} / \mathrm{mL}, 51 \mathrm{IU} / \mathrm{mL}, 17 \mathrm{mg} / \mathrm{L}$ and $528 \mathrm{ng} / \mathrm{mL}$, respectively) or in patients with cured $\mathrm{HCV}$ infection $(37 \mathrm{IU} / \mathrm{mL}, 29 \mathrm{IU} / \mathrm{mL}, 3.4 \mathrm{mg} / \mathrm{L}$ and $274 \mathrm{ng} / \mathrm{mL}$, respectively). Also, serum and fecal calprotectin had increased concentrations in patients with COVID-19 $(7.3 \mu \mathrm{g} / \mathrm{mL}$ and $394 \mu \mathrm{g} / \mathrm{mg})$ versus patients with active hepatitis $(2.4 \mu \mathrm{g} / \mathrm{mL}$ and $217 \mu \mathrm{g} / \mathrm{mg})$ and patients with cured hepatitis $(1.2 \mu \mathrm{g} / \mathrm{mL}$ and $38 \mu \mathrm{g} / \mathrm{mg})$. Values were significantly higher in patients with digestive symptoms related to COVID-19. Serum and fecal calprotectin can be used as inflammatory markers in patients with active viral infections. In COVID-19, calprotectin concentrations can be correlated to the severity of disease, particularly in patients with digestive symptoms.
\end{abstract}

Keywords Calprotectin $\cdot$ Inflammation $\cdot$ Systemic infection $\cdot$ COVID-19 $\cdot$ HCV

\section{Introduction}

Calprotectin, pertaining to the S-100 family, is a calcium and zinc-binding protein, forming about $60 \%$ of the cytosolic proteins of neutrophils [1]. It plays an important role in the pathogenesis of inflammation as ligand for toll-like receptor 4 , mediator for the migration of polymorphonuclear leukocytes and up-regulator for neutrophils [2]. Furthermore, the interaction between calprotectin and RAGE (Receptor for Advanced Glycation End products) activates nuclear factorkappa $\beta$ inducing the release of pro-inflammatory cytokines; this mechanism has been incriminated in the development and progression of atherosclerosis [3].

Letitia Toma

Letitia_toma@yahoo.com

1 "Carol Davila" University of Medicine and Pharmacy, Bucharest, Romania

2 Department of Internal Medicine, Fundeni Clinical Institute, Bucharest, Romania
The majority of studies regarding calprotectin as inflammatory marker comes from inflammatory bowel diseases (IBDs), where high concentrations of serum and fecal calprotectin are associated with increased severity scores [4]. International guidelines for Crohn's disease and ulcerative colitis recommend using calprotectin determinations for the diagnosis and monitoring of IBDs [5, 6]. The most important use of fecal calprotectin remains in the differential diagnosis of IBDs versus irritable bowel syndrome, thus underlining its importance as an inflammatory marker [7]. Increased fecal calprotectin concentrations have also been described in patients with ankylosing spondylitis, without gastrointestinal symptoms, as a marker of subclinical intestinal inflammation [8]. Other studies have demonstrated the importance of calprotectin as biomarker of cystic fibrosis exacerbations [9], adult-onset Still's disease [10] or other arthropathies [11].

The exacerbated immune response associated with COVID-19 is the leading cause of morbidity and mortality in this infection. As such, monitoring patients by serial determinations of inflammatory markers is crucial in the 
management of these patients [12]. Hyperinflammation in COVID-19 appears to be the result of a dysregulated activation of the mononuclear phagocyte compartment [13] as well as down-regulation of angiotensin-converting enzyme 2 (ACE2) leading to the dysregulation of the renin-angiotensin-aldosterone system, stimulation of the bradykinin axis and activation of the complement systems [14]. Serum calprotectin has been evaluated as a biomarker for the differentiation between mild and severe forms of COVID-19 infection [15]. In a recent review, levels of serum calprotectin correlated with other inflammatory markers, such as IL-6, C-reactive protein (CRP), neutrophil count and D-dimers [16].

The systemic inflammatory response is also responsible for a variety of manifestations in chronic hepatitis $\mathrm{C}$ (HCV) infection, including liver damage (chronic hepatitis, cirrhosis, hepatocellular carcinoma) and extrahepatic manifestations [17]. It is currently considered that up to $66 \%$ of $\mathrm{HCV}$-infected patients experience extrahepatic manifestations, mainly autoimmune or lymphoproliferative disorders [18]. These include non-Hodgkin lymphoma [19] cryoglobulinemia [20], diabetes [21] or rare associated conditions such as sarcoidosis [22]. The use of calprotectin as biomarker has been studied in regard to the early diagnosis of hepatic encephalopathy, spontaneous bacterial peritonitis and hepatocellular carcinoma in $\mathrm{HCV}$-induced cirrhosis [23, 24]. In the studies aforementioned, fecal and ascites calprotectin determinations were performed; data regarding serum calprotectin as inflammatory marker in $\mathrm{HCV}$ chronic infection are scarce. One study has also found significant correlations between fecal concentrations of calprotectin and the severity of $\mathrm{HCV}$-induced liver disease [25].

\section{Materials and methods}

The aim of our study is to compare values of serum and fecal calprotectin in patients with COVID-19 infection, active $\mathrm{HCV}$ chronic infection and cured HCV infection, in order to underline the importance of calprotectin as an inflammatory biomarker in acute and chronic viral infections. From April 2020 to October 2020, we performed an observational study enrolling consecutive patients diagnosed with COVID-19 infection without chronic hepatitis, patients with ongoing $\mathrm{HCV}$ chronic infection and patients with cured HCV infection (at least 1 year after sustained virologic response after direct acting antiviral therapy). The study was approved by the local Ethics Committee. Patients signed an informed consent form on hospital admission, approving the use of their demographic, clinical and biological data for scientific purposes. All the patients received medical care according to current guidelines, and no study-related interventions were taken.
The diagnosis of COVID-19 infection was made by SARS-CoV-2 RNA detection via reverse-transcription polymerase chain reaction (RT-PCT) from the upper respiratory tract (both nasal and pharyngeal swabs) using Cobas ${ }^{\circledR}$ SARS-CoV-2 Test (Roche Diagnostics, F. Hoffmann-La Roche, Ltd, Basil, SW). Active HCV infection was diagnosed using positive anti-HCV antibodies and values of HCV viremia quantitatively assessed by RT-PCR. Patients with cured HCV infection had undetectable HCV-RNA at 3 months after the end of DAA therapy (paritaprevir/ombitasvir/ritonavir and dasabuvir).

Exclusion criteria were:

- Hepatitis B virus or HIV co-infection

- Presence of liver cirrhosis

- History of or ongoing autoimmune diseases

- Suspicion of inflammatory bowel disease

- Past or present treatment with anti-inflammatories (steroidal or nonsteroidal) or immune modulators

- The presence of solid or hematological malignancies (except history of non-melanoma skin cancer)

Patients with solid or hematologic malignancies have been excluded due to the chronic inflammatory syndrome associated with these conditions [26]. It has been shown that there is an inflammatory microenvironment within tumors, consisting mainly of leukocytes [27]. Also, the progression of liver disease to cirrhosis is associated with a chronic systemic inflammation and dysregulation of the immune system [28].

After applying the exclusion criteria, a total of 93 patients were evaluated: 25 patients with COVID-19 infection, 30 patients with active HCV chronic infection and 38 patients with cured HCV infection. Patients with COVID-19 infection were classified according to the WHO recommendations [29]. Thus, patients were considered to have mild disease if they were symptomatic but had no signs of pneumonia or hypoxia or moderate disease if they had clinical signs of pneumonia but maintaining oxygen saturation levels over $90 \%$ in room air.

We determined serum levels of transaminases, C-reactive protein, serum ferritin, serum and fecal calprotectin. We also performed clinical evaluation of the patients and noted data referring to digestive symptoms: diarrhea, nausea and abdominal pain. Blood samples were taken a jeun, within $24 \mathrm{~h}$ of hospital admission via a peripheral vein and biological assays were performed within $1 \mathrm{~h}$. CRP was determined by latex-enhanced immunoturbidimetry using a reference value of less than $0.5 \mathrm{mg} / \mathrm{dL}$. Ferritin levels were determined by electrochemiluminescence; while normal values vary significantly in children and adolescence, considering all our patients were adult we considered normal values between $13-150 \mathrm{ng} / \mathrm{mL}$ for women and $30-400 \mathrm{ng} / \mathrm{mL}$ for men. 
ELISA kits were used for determination of serum calprotectin, as provided by the local laboratory. Stool samples were also collected within $24 \mathrm{~h}$ of admission in sterile recipients and were transported at temperatures from 2 to 8 degrees Celsius to the local laboratory. ELISA kits were also used to determine fecal calprotectin concentrations, with a detection limit of $30 \mathrm{mg} / \mathrm{g}$. Cutoff values for significant digestive inflammation were $90 \mathrm{mg} / \mathrm{g}$. In normal subjects, levels of 50 to $90 \mathrm{mg} / \mathrm{g}$ were considered as susceptible for inflammation, but with a low probability.

Statistical evaluation was performed using SPSS 18.0 (SPSS Inc., Chicago, IL, USA). We used the expression of numerical values as mean \pm standard deviation. The ANOVA test was used to compare the values between the three groups of patients. A $P$ value of less than 0.05 was considered statistically significant for differences between values.

\section{Results}

All COVID-19 patients had asymptomatic or mild disease. Twenty percent required noninvasive oxygen therapy to maintain saturation levels over $95 \%$, according to current guidelines. In ambient air, none of the patients had oxygen saturation less than $90 \%$.

The mean age in the study group was $47 \pm 23.15$ years, with a predominance of the female sex in each study group. The results of the study are presented in Table 1.
Significantly higher levels of ALT and AST were noted in patients with COVID-19 infection compared to patients with active or cured HCV infection. Furthermore, levels of CRP and ferritin were also increased in patients with COVID19 , as well as patients with active HCV infection, supporting the idea that there is systemic inflammation associated with these infections. Both serum and fecal calprotectin had higher concentrations in patients with COVID-19, compared to patients with active or cured $\mathrm{HCV}$ infection. As results in patients with cured HCV are within normal range, we can conclude that HCV cure signifies the abolishment of systemic inflammation in patients without comorbidities, and these may be considered as a normal population (a control group).

Thirty-six percent of COVID-19-infected patients presented gastrointestinal symptoms, as opposed to $43.33 \%$ patients with active HCV and $13.15 \%$ patients with cured $\mathrm{HCV}$. None of the symptoms were suggestive for other gastrointestinal disease, and samples for bloody stools were negative. The prevalence of symptoms is presented in Table 2

Patients with HCV infection had the highest prevalence of digestive symptoms; the most frequently encountered were diarrhea, abdominal pain and nausea. Diarrhea was significantly associated with COVID-19 infection, while abdominal pain and nausea were found in patients with COVID-19 as well as active $\mathrm{HCV}$, with increased prevalence compared to the control group (cured HCV). Notably, the presence of

Table 1 Demographic and biologic characteristic of the study groups

\begin{tabular}{|c|c|c|c|c|}
\hline & $\begin{array}{l}\text { Patients with COVID-19 } \\
(n=25 \text { pts })\end{array}$ & $\begin{array}{l}\text { Patients with active } \mathrm{HCV} \\
(n=30 \mathrm{pts})\end{array}$ & $\begin{array}{l}\text { Patients with cured HCV } \\
(n=38 \mathrm{pts})\end{array}$ & $P$ value \\
\hline Mean age & $49.23 \pm 25.16$ & $53.15 \pm 24.62$ & $47.91 \pm 22.05$ & 0.4 \\
\hline Female gender & $14(56 \%)$ & $20(66.6 \%)$ & $22(57.8 \%)$ & 0.3 \\
\hline $\operatorname{ALT}(N: 0-45 \mathrm{UI} / \mathrm{mL})$ & $127 \pm 26$ & $68 \pm 22$ & $37 \pm 12$ & 0.01 \\
\hline $\operatorname{AST}(N: 0-35 \mathrm{IU} / \mathrm{mL})$ & $135 \pm 54$ & $51 \pm 28$ & $29 \pm 15$ & 0.02 \\
\hline $\mathrm{CRP}(N: 0-3 \mathrm{mg} / \mathrm{L})$ & $127.4 \pm 59.3$ & $17.2 \pm 8.3$ & $3.4 \pm 1.8$ & 0.01 \\
\hline \multirow{2}{*}{$\begin{array}{l}\text { Ferritin }(N \bigcirc: 13-150 \mathrm{ng} / \mathrm{mL} \\
\left.N^{\lambda}: 30-400 \mathrm{ng} / \mathrm{mL}\right)\end{array}$} & $945 \pm 118$ & $371 \pm 101$ & $78 \pm 27$ & 0.01 \\
\hline & $1034 \pm 231$ & $528 \pm 94$ & $274 \pm 112$ & 0.01 \\
\hline Serum calprotectin $(N: 0.1-1.6 \mu \mathrm{g} / \mathrm{mL})$ & $7.3 \pm 2.6$ & $2.4 \pm 1.1$ & $1.2 \pm 0.4$ & 0.03 \\
\hline Fecal calprotectin $(N: 10-60 \mu \mathrm{g} / \mathrm{mg})$ & $394.2 \pm 77.1$ & $217.7 \pm 92.7$ & $38.5 \pm 11.6$ & 0.01 \\
\hline
\end{tabular}

$A L T$ alanine aminotransferase, $A S T$ aspartate aminotransferase, $C R P$ C-reactive protein

Table 2 Prevalence of digestive symptoms in the study groups

\begin{tabular}{llccc}
\hline & Patients with COVID- & Patients with active & Patients with cured & $P$ value \\
& $19(N=25 \mathrm{pts})$ & $\mathrm{HCV}(N=30 \mathrm{pts})$ & $\mathrm{HCV}(N=38 \mathrm{pts})$ & \\
\hline Digestive symptoms & $36 \%(9 \mathrm{pts})$ & $43.33 \%(13 \mathrm{pts})$ & $13.15 \%(5 \mathrm{pts})$ & 0.4 \\
Diarrhea & $32 \%(8 \mathrm{pts})$ & $6,66 \%(2 \mathrm{pts})$ & $0 \%(0 \mathrm{pts})$ & 0.01 \\
Abdominal pain & $24 \%(6 \mathrm{pts})$ & $23.33 \%(7 \mathrm{pts})$ & $7.89 \%(3 \mathrm{pts})$ & 0.02 \\
Nausea & $28 \%(7 \mathrm{pts})$ & $30 \%(9 \mathrm{pts})$ & $7.89 \%(3 \mathrm{pts})$ & 0.02 \\
\hline
\end{tabular}


digestive symptoms was associated with increased levels of serum and fecal calprotectin ( $P$ value 0.01 and 0.02 , respectively, CI 95\%).

A sub-analysis shows that COVID-19-infected patients with digestive symptoms had higher levels of serum and fecal calprotectin compared to patients without digestive symptoms (Table 3). However, there results should be regarded cautiously due to the low number of patients.

\section{Discussion}

The COVID-19 pandemic is a continuous challenge of medical systems worldwide, but it has also proven an opportunity for scientific research, particularly in the field of immunology, as understanding the systemic inflammatory response is critical for the diagnosis and proper management of this altogether systemic infection [30]. Apart from the intrinsic morbidity and mortality, COVID-19 has negatively impacted the prognosis of patients with chronic diseases, such as HCV chronic infection [31].

There are biological and clinical similarities between HCV and COVID-19. Most of the current information comes from extrapolation of the results obtained in studying the SARS-CoV and the MERS pandemic [32]. Important similarities are the induction of channelopathies as a pathologic mechanism, the involvement of $\mathrm{T}$ helper lymphocytes (in the carcinogenesis of $\mathrm{HCV}$ and in the cytokine dysregulation associated with the early stage of SARS-CoV infection) and the response to interferon therapy. From a clinical point of view, both viruses trigger inflammatory responses in multiple organs, leading to systemic disease by direct or indirect mechanisms. It is well known that HCV infection causes multiple extrahepatic manifestations [33] and HCV cure is associated with a favorable outcome of the liver disease and also on HCV-induced comorbidities, such as cryoglobulinemia and lymphoma [34].

Symptoms of HCV chronic infection are non-specific, regardless of the stage of liver disease, with a recent study pointing to $40-50 \%$ of patients with gastrointestinal complaints [35]. A recent review, including a total of over 18,000 patients, found that COVID-19 frequently manifests with digestive symptoms (11.5\% of patients and as many as $30 \%$ in some studies), the most common symptoms being diarrhea $(11.5 \%)$, nausea and vomiting $(6.3 \%)$ and abdominal pain $(2.3 \%)$; cases of intestinal bleeding were also reported [36]. In our study, we found a higher prevalence of overall gastrointestinal symptoms (36\%) as well as diarrhea (32\%), nausea (24\%) and abdominal pain (28\%). None of the patients in our study group presented intestinal bleeding. The higher prevalence of gastrointestinal symptoms can be explained by the selective addressability of patients; as our Clinic focuses primarily on gastroenterology and hepatology, patients with digestive symptoms are more likely to appeal to us. We did not include ageusia and anosmia as gastrointestinal symptoms of COVID-19 as these are more likely to be receptor and neuronal dysfunctions [37, 38].

Inflammation is a key factor in both HCV and COVID-19 infection. HCV infection promotes a chronic inflammatory process in the liver, involving IL-1 $\beta$ production and secretion by liver macrophages, increased production of TNF $-\alpha$ and activation of Toll-like receptors [17]. In addition, chronic HCV infection is associated with intestinal bacterial overgrowth, leading to endotoxemia, liver and systemic inflammation [39]. This is one possible explanatory mechanism for the increased concentration of serum and fecal calprotectin in patients with active infection, compared to those with cured infection, as described in our study. Furthermore, the exclusion of patients with advanced liver disease (compensated or decompensated cirrhosis) means that there is significant inflammation due to the infection per se and not due to the degree of liver fibrosis. Inflammation in $\mathrm{HCV}$ infection is maintained by a vicious circle, as $\mathrm{HCV}$ is an inductor of liver steatosis (which induces oxidative stress and the activation of stellate cells [40] and insulin resistance and diabetes mellitus (via TNF- $\alpha$ pathways) [41]. This may contribute to the pro-inflammatory state that is the HCV chronic infection and may explain our findings of increases CRP and ferritin levels in patients without other causes of systemic inflammation. Studies have found that increased ferritin levels in chronic HCV hepatitis are associated with insulin resistance [42] and diabetes [43]. On the other hand, it has been shown that ferritin levels decrease at 24 weeks after HCV cure by direct acting antiviral therapy [44].

COVID-19 affects the digestive system directly, by infecting the gastrointestinal cells via ACE2 receptors (100 fold
Table 3 Comparison between inflammatory markers in COVID-19 patients with and without digestive symptoms

\begin{tabular}{|c|c|c|c|}
\hline & $\begin{array}{l}\text { Patients with digestive } \\
\text { symptoms ( } 9 \text { pts) }\end{array}$ & $\begin{array}{l}\text { Patients without digestive } \\
\text { symptoms (16 pts) }\end{array}$ & \\
\hline $\mathrm{CRP}(N: 0-3 \mathrm{mg} / \mathrm{L})$ & $134.3 \pm 52.7$ & $114.7 \pm 55.1$ & $P=0.5$ \\
\hline \multirow{2}{*}{$\begin{array}{l}\text { Ferritin }(N+: 13-150 \mathrm{ng} / \mathrm{mL} \\
\left.N^{\wedge}: 30-400 \mathrm{ng} / \mathrm{mL}\right)\end{array}$} & $879 \pm 166$ & $921 \pm 124$ & $P=0.4$ \\
\hline & $1012 \pm 195$ & $978 \pm 258$ & $P=0.5$ \\
\hline Serum calprotectin $(N: 0.1-1.6 \mu \mathrm{g} / \mathrm{mL})$ & $9.4 \pm 1.6$ & $7.7 \pm 1.8$ & $P=0.04$ \\
\hline Fecal calprotectin $(N: 10-60 \mu \mathrm{g} / \mathrm{mg})$ & $442.4 \pm 39.5$ & $298.4 \pm 83.7$ & $P=0.03$ \\
\hline
\end{tabular}


more frequent in the small intestine and the colon than in the lungs) and indirectly, by triggering a systemic inflammatory response, a "cytokine storm," leading to multiple organ dysfunction, including the digestive tract [45]. The presence of ACE2 receptors in the absorptive enterocytes and consecutive COVID-19 infection may explain the presence of diarrhea as a common symptom of infection [46]. In our study, 32\% of COVID-19 patients presented diarrhea, and this was the most frequent gastrointestinal symptom. Furthermore, COVID-19 may reduce the absorption of tryptophan at an enteric level, inducing intestinal inflammation and colitis [45]. Intestinal dysbiosis, with decreased concentration of Lactobacillus and Bifidobacterium species, may also explain the digestive symptoms associated with COVID-19 [47]. Inflammatory markers are essential in establishing the severity of COVID-19 infection as well as prognosis and management [48]. Elevated CRP levels are associated with increased disease severity, but not increased mortality, as opposed to high levels of ferritin, which mark a poor prognosis. However, cutoff values differ significantly between studies (from $3 \mathrm{mg} / \mathrm{L}$ to over $100 \mathrm{mg} / \mathrm{L}$ for CRP). The role and importance of ferritin in COVID-19 infection is still under debate. It appears to be related to the development of secondary hemophagocytic lymphohistiocytosis leading to multiple organ dysfunction [49]. In our study, we found significantly higher levels of CRP and ferritin in COVID19 patients, compared to HCV-infected patients and to the control group. Despite this, none of the patients presented a poor outcome or intensive care requirements. The use of calprotectin as a marker for inflammatory bowel disease has known a setback since the beginning of the COVID-19 outbreak, as many studies have associated increased concentrations of fecal calprotectin to the presence and severity to the COVID-19 digestive symptoms [50]. The evolution of fecal calprotectin in COVID-19-infected patients with inflammatory bowel diseases needs to be further investigated.

In our study, we have shown that both fecal and serum calprotectin have increased concentrations during COVID19 infection, and these concentrations correlate with the severity of digestive symptoms. Patients with COVID-19 related digestive symptoms are more likely to have increased calprotectin levels than patients without digestive symptoms, in the setting of similar systemic inflammation as denoted by CRP and ferritin levels. The fact that serum calprotectin is increased in COVID-19 infection is an argument in favor of categorizing this as a marker of systemic inflammation rather than strictly a digestive one. In addition, levels of calprotectin were increased in patients without digestive symptoms, also suggesting its role as a systemic marker.

The comparison of COVID-19 patients to HCV-infected patients and healthy subjects is meant to underline the importance of calprotectin as a systemic inflammatory marker, demonstrating increased concentrations in different infectious pathologies associated with an exaggerated immune response. Another important aspect of this comparison is proving that COVID-19 patients have significantly increased calprotectin levels, thus raising the suspicion of infection in symptomatic patients.

Our study has several drawbacks. First, the number of patients is relatively low in each group, and the attempt to compare between sub-groups of COVID-19 patients borders the limits of statistical significance. Second, inflammatory markers were collected on hospital admission without taking into account the number of days since the beginning of the symptoms or the potential infectious contact. Third, serum and fecal calprotectin were not monitored periodically and we cannot establish the evolution of their values according to the moment of infection. However, we consider that serum and fecal calprotectin may be of use in the diagnosis and evaluation of patients with COVID-19 infection, along other inflammatory markers, most importantly in patients with digestive symptoms.

\section{Conclusion}

Viral infections such as HCV and COVID-19 are associated with increased inflammatory markers, as a sign of the systemic immune response triggered by the infections. Serum and fecal calprotectin may be of further use in monitoring of inflammation during the course of viral infections, but further research is needed in order to establish cutoff prognostic values. Our study shows that increased calprotectin concentrations are associated with COVID-19 infection, especially in patients with digestive symptoms.

Authors' contributions All authors contributed equally to this research and its publication.

Funding The authors did not receive support from any organization for the submitted work.

Availability of data and material Data were obtained by electronic and written patient charts.

\section{Declarations}

Conflict of interest The authors have no relevant financial or non-financial interests to disclose.

Ethics approval This study was performed in line with the principles of the Declaration of Helsinki. Approval was waived by the Ethics Committee of Fundeni Clinical Institute given that this research study was conducted retrospectively from data obtained for clinical purposes.

Consent to participate Informed consent was obtained from all individual participants included in the study. 
Consent for publication The authors affirm that human research participants provided informed consent for publication.

\section{References}

1. Fagherol MK, Andersson KB, Naess-Andresen CF, Brandtzaeg P, Dale I. Calprotectin (the L1 leucocyte protein). In: Smith VL, Dedman JR, editors. Stimulus response coupling: the role of intracellular calcium-binding proteins. Boca Raton: CRC Press; 1990. p. $187-210$.

2. Azramezani Kopi T, Shahrokh S, Mirzaei S, Asadzadeh Aghdaei $\mathrm{H}$, Amini Kadijani A. The role of serum calprotectin as a novel biomarker in inflammatory bowel diseases: a review study. Gastroenterol Hepatol Bed Bench. 2019;12(3):183-9.

3. Hauzer W, Witkiewicz W, Gnus J. Calprotectin and receptor for advanced glycation end products as a potential biomarker in abdominal aortic aneurysm. J Clin Med. 2020;9(4):927. https:// doi.org/10.3390/jcm9040927.

4. e Penna FGC, Rosa RM, da Cunha PFS, et al. Faecal calprotectin is the biomarker that best distinguishes remission from different degrees of endoscopic activity in Crohn's disease. BMC Gastroenterol. 2020;20:35. https://doi.org/10.1186/s12876-020-1183-x.

5. Lichtenstein GR, Loftus EV, Isaacs KL, Regueiro MD, Gerson LB, Sands BE. ACG clinical guideline: management of Crohn's disease in adults. Am J Gastroenterol. 2018;113(4):481-517. https://doi.org/10.1038/ajg.2018.27.

6. Rubin DT, Ananthakrishnan AN, Siegel CA, Sauer BG, Long MD. ACG clinical guideline: ulcerative colitis in adults. Am J Gastroenterol. 2019;114(3):384-413. https://doi.org/10.14309/ ajg.0000000000000152.

7. Chang M, Chou J, Chen S, et al. Fecal calprotectin as a novel biomarker for differentiating between inflammatory bowel disease and irritable bowel syndrome. Mol Med Rep. 2014;10:522-6.

8. Klingberg E, Carlsten H, Hilme E, Hedberg M, Forsbladd'Elia H. Calprotectin in ankylosing spondylitis-frequently elevated in feces, but normal in serum. Scand J Gastroenterol. 2012;47(4):435-44. https://doi.org/10.3109/00365521.2011. 648953.

9. Gray RD, Imrie M, Boyd AC, Porteous D, Innes JA, Greening AP. Sputum and serum calprotectin are useful biomarkers during CF exacerbation. J Cyst Fibros. 2010;9(3):193-8. https://doi.org/10. 1016/j.jcf.2010.01.005.

10. Guo Q, Zha X, Li C, et al. Serum calprotectin-a promising diagnostic marker for adult-onset Still's disease. Clin Rheumatol. 2016;35(1):73-9. https://doi.org/10.1007/s10067-015-3108-6.

11. Jarlborg M, Courvoisier DS, Lamacchia C, et al. Serum calprotectin: a promising biomarker in rheumatoid arthritis and axial spondyloarthritis. Arthritis Res Ther. 2020;22:105. https://doi.org/ 10.1186/s13075-020-02190-3.

12. COVID-19 Treatment Guidelines Panel. Coronavirus Disease 2019 (COVID-19) Treatment Guidelines. National Institutes of Health. https://www.covid19treatmentguidelines.nih.gov/. Accessed 19 Apr 2021.

13. Merad M, Martin JC. Pathological inflammation in patients with COVID-19: a key role for monocytes and macrophages. Nat Rev Immunol. 2020;20:355-62. https://doi.org/10.1038/ s41577-020-0331-4.

14. Mahmudpour M, Roozbeh J, Keshavarz M, Farrokhi S, Nabipour I. COVID-19 cytokine storm: the anger of inflammation. Cytokine. 2020;133:155151.

15. Silvin A, Chapuis N, Dunsmore G, et al. Elevated calprotectin and abnormal myeloid cell subsets discriminate severe from mild COVID-19. Cell. 2020;182(6):1401-1418.e18. https://doi. org/10.1016/j.cell.2020.08.002.

16. Mahler M, Meroni PL, Infantino M, Buhler KA, Fritzler MJ. Circulating calprotectin as a biomarker of COVID-19 severity. Expert Rev Clin Immunol. 2021. https://doi.org/10.1080/17446 66X.2021.1905526.

17. Zampino R, Marrone A, Restivo L, et al. Chronic HCV infection and inflammation: clinical impact on hepatic and extra-hepatic manifestations. World J Hepatol. 2013;5(10):528-40. https:// doi.org/10.4254/wjh.v5.i10.528.

18. Cacoub P, Comarmond C, Domont F, Savey L, Desbois AC, Saadoun D. Extrahepatic manifestations of chronic hepatitis $C$ virus infection. Ther Adv Infect Dis. 2016;3(1):3-14. https:// doi.org/10.1177/2049936115585942.

19. Iliescu L, Mercan-Stanciu A, Ioanitescu ES, Toma L. Hepatitis C-associated B-cell non-Hodgkin lymphoma: a pictorial review. Ultrasound Q. 2018;34(3):156-66.

20. Iliescu EL, Mercan-Stanciu A, Toma L. Safety and efficacy of direct-acting antivirals for chronic hepatitis $\mathrm{C}$ in patients with chronic kidney disease. BMC Nephrol. 2020;21:21.

21. Iliescu L, Mercan-Stanciu A, Toma L, Ioanitescu ES. A severe case of hyperglycemia in a kidney transplant recipient undergoing interferon-free therapy for chronic hepatitis C. Acta Endocrinol (Buchar). 2018;14(4):533-8.

22. Iliescu L, Herlea V, Toma L, Orban C. Association between chronic HCV hepatitis, membranoproliferative glomerulopathy and cutaneous sarcoidosis. J Gastrointest Liver Dis. 2015;24(1):8.

23. Elnaggar YA, Zidan HE, Abdelbaky EM, Wadea FM. Association of increased fecal calprotectin levels with hepatic encephalopathy and spontaneous peritonitis in Egyptian cirrhotic patients. J Gastroenterol Hepatol Res. 2020;9(3):3217-22.

24. Hanafy AS, Mohamed MS, Alnagar AA. Ascitic Calprotectin as an early predictor of hepatocellular carcinoma in patients with cirrhotic ascites. J Cancer Res Clin Oncol. 2020;146(12):3207-14. https://doi.org/10.1007/s00432-020-03363-y.

25. El-Din M, Salem H, Mansour MA, El saady Khayyal A, Mohsen M, Mansour K. Relation between Fecal Calprotectin concentration and severity of Hepatitis $\mathrm{C}(\mathrm{HCV})$ related chronic liver disease. Int J Adv Res Biol Sci. 2015;2(7):115-25.

26. Singh N, Baby D, Rajguru JP, Patil PB, Thakkannavar SS, Pujari VB. Inflammation and cancer. Ann Afr Med. 2019;18(3):121-6. https://doi.org/10.4103/aam.aam_56_18.

27. Negus RP, Stamp GW, Hadley J, Balkwill FR. Quantitative assessment of the leukocyte infiltrate in ovarian cancer and its relationship to the expression of C-C chemokines. Am J Pathol. 1997;150:1723-34.

28. Dirchwolf M, Ruf AE. Role of systemic inflammation in cirrhosis: From pathogenesis to prognosis. World J Hepatol. 2015;7(16):1974-81. https://doi.org/10.4254/wjh.v7.i16.1974.

29. Clinical management of COVID-19: living guidance, WHO REFERENCE NUMBER: WHO/2019-nCoV/clinical/2021.1. https://www.who.int/publications/i/item/WHO-2019-nCoV-clini cal-2021-1. Accessed 3rd June 2021.

30. Chowdhury MA, Hossain N, Kashem MA, Shahid MA, Alam A. Immune response in COVID-19: a review. J Infect Public Health. 2020;13(11):1619-29. https://doi.org/10.1016/j.jiph.2020.07.001.

31. Blach S, Kondili LA, Aghemo A, et al. Impact of COVID-19 on global HCV elimination efforts. J Hepatol. 2021;74(1):31-6. https://doi.org/10.1016/j.jhep.2020.07.042.

32. Alothaid H, Aldughaim M, El Bakkouri K, AlMashhadi S, AlQahtani AA. Similarities between the effect of SARS-CoV-2 and $\mathrm{HCV}$ on the cellular level, and the possible role of ion channels in COVID19 progression: a review of potential targets for diagnosis and treatment. Channels (Austin, TX). 2020;14(1):403-12. https:// doi.org/10.1080/19336950.2020.1837439. 
33. Kaplan DE. Hepatitis $\mathrm{C}$ virus. Ann Intern Med. 2020;173(5):ITC33-48. https://doi.org/10.7326/AITC202009010.

34. Mohanty A, Salameh S, Butt AA. Impact of direct acting antiviral agent therapy upon extrahepatic manifestations of hepatitis $\mathrm{C}$ virus infection. Curr HIV/AIDS Rep. 2019;16(5):389-94. https:// doi.org/10.1007/s11904-019-00466-1.

35. Evon DM, Stewart PW, Amador J, et al. A comprehensive assessment of patient reported symptom burden, medical comorbidities, and functional well being in patients initiating direct acting antiviral therapy for chronic hepatitis C: results from a large US multicenter observational study. PLoS ONE. 2018;13(8): e0196908. https://doi.org/10.1371/journal.pone.0196908.

36. Silva F, Brito BB, Santos M, et al. COVID-19 gastrointestinal manifestations: a systematic review. Rev Soc Bras Med Trop. 2020;53:e20200714. https://doi.org/10.1590/ 0037-8682-0714-2020.

37. Vaira LA, Salzano G, Deiana G, De Riu G. Anosmia and ageusia: common findings in COVID-19 patients. Laryngoscope. 2020;130(7):1787. https://doi.org/10.1002/lary.28692.

38. Vaira LA, Salzano G, Fois AG, Piombino P, De Riu G. Potential pathogenesis of ageusia and anosmia in COVID-19 patients. Int Forum Allergy Rhinol. 2020;10(9):1103-4. https://doi.org/10. 1002/alr.22593.

39. Sandler NG, Koh C, Roque A, et al. Host response to translocated microbial products predicts outcomes of patients with HBV or HCV infection. Gastroenterology. 2011;141(1220-1230):1230. e1-e3.

40. Leandro G, Mangia A, Hui J, et al. Relationship between steatosis, inflammation, and fibrosis in chronic hepatitis C: a meta-analysis of individual patient data. Gastroenterology. 2006;130:1636-42.

41. Knobler H, Schattner A. TNF- $\alpha$, chronic hepatitis $\mathrm{C}$ and diabetes: a novel triad. QJM. 2005;98:1-6.

42. Elsammak M, Refai W, Elsawaf A, Abdel-Fattah I, Abd Elatti E, Ghazal A. Elevated serum tumor necrosis factor alpha and ferritin may contribute to the insulin resistance found in HCV positive Egyptian patients. Curr Med Res Opin. 2005;21(4):527-33. https://doi.org/10.1185/030079905X38141.
43. Lecube A, Hernández $\mathrm{C}$, Genescà $\mathrm{J}$, et al. Diabetes is the main factor accounting for the high ferritin levels detected in chronic hepatitis C virus infection. Diabetes Care. 2004;27(11):2669-75. https://doi.org/10.2337/diacare.27.11.2669.

44. Chang ML, Hu JH, Yen $\mathrm{CH}$, et al. Evolution of ferritin levels in hepatitis $C$ patients treated with antivirals. Sci Rep. 2020;10:19744. https://doi.org/10.1038/s41598-020-76871-z.

45. Chunxiang M, Yingzi C, Hu Z. COVID-19 and the digestive system. Am J Gastroenterol. 2020;115(7):1003-6. https://doi.org/10. 14309/ajg.0000000000000691.

46. Zhang H, Kang Z, Gong H, et al. Digestive system is a potential route of COVID-19: an analysis of single-cell coexpression pattern of key proteins in viral entry process. Gut. 2020;69:1010-8. https://doi.org/10.1136/gutjnl-2020-320953.

47. Xu K, Cai H, Shen Y, et al. Management of corona virus disease-19 (COVID-19): The Zhejiang experience. Zhejiang Da Xue Xue Bao Yi Xue Ban. 2020;49(1):147-57.

48. Huang I, Pranata R, Lim MA, Oehadian A, Alisjahbana B. C-reactive protein, procalcitonin, D-dimer, and ferritin in severe coronavirus disease-2019: a meta-analysis. Ther Adv Respir Dis. 2020;14:1753466620937175. https://doi.org/10.1177/1753466620 937175.

49. Mehta P, McAuley DF, Brown M, et al. COVID-19: consider cytokine storm syndromes and immunosuppression. Lancet. 2020;395:1033-4.

50. Jena A, Kumar-MP Singh AK, Sharma V. Fecal calprotectin levels in COVID-19: lessons from a systematic review on its use in inflammatory bowel disease during the pandemic. Dig Liver Dis. 2021;53(3):295-7. https://doi.org/10.1016/j.dld.2020.10.021.

Publisher's Note Springer Nature remains neutral with regard to jurisdictional claims in published maps and institutional affiliations. 